ISSN 0206-5657. Вісник Львівського університету. Серія біологічна. 2019 Випуск 80. С. 82-89 Visnyk of the Lviv University. Series Biology. 2019. Issue 80. P. 82-89

УДК 577.2:633.1 https://doi.org/10.30970/vlubs.2019.80.10

\title{
HAPLOTYPES OF PPD-D1 GENE AND ALLELES OF PPD-A1 AND PPD-B1 IN UKRAINIAN BREAD WHEAT VARIETIES
}

\author{
G. Chebotar ${ }^{1}$, A. Bakuma ${ }^{1}$, V. Filimonov ${ }^{1}$, S. Chebotar ${ }^{1,2 *}$ \\ ${ }^{1}$ Department of Genetics and Molecular Biology \\ Odesa National I.I. Mechnikov University \\ 2, Dvoryanska St., Odesa 65082, Ukraine \\ ${ }^{2}$ Plant Breeding and Genetics Institute - \\ National Center of Seed and Cultivar Investigation \\ 3, Ovidiopolska Road, Odesa 65036, Ukraine \\ *e-mail: s.v.chebotar@onu.edu.ua
}

\begin{abstract}
Modern Ukrainian bread wheat varieties are not enough characterized by the alleles of $P p d$ genes and there is very restricted information about haplotypes of these genes in Ukrainian wheat genetic pool. The dominant alleles (a) of Ppd-Al (2A), Ppd-Bl(2B), $P p d-D 1$ (2D) genes reduce sensitivity to photoperiod thus shorten the period until earing and genotypes with recessive alleles $(b)$ have a strong reaction to the photoperiod. Haplotypes of $P p d-D 1$ gene could also affect photoperiod sensitivity. According to PCR analysis with allele specific primers most investigated varieties were characterized by $P p d-A 1 b$ and $P p d-$ $B 1 b$ alleles. 40 varieties $(81.2 \%)$ had the deletion upstream the coding region of $P p d-D 1$ gene, that distinguish $P p d-D 1 a$ allele. Also, we analyzed haplotypes of $P p d-D 1$ gene. There was shown presence of VII haplotype of $P p d-D 1$ gene for $79.6 \%$ of varieties. The varieties with I (2\%), II (6\%), III (10\%) haplotypes of the Ppd-DI gene were less frequent. One variety was heterogeneous by $P p d-D l a / b$ alleles. From the tested ones only varieties of winter bread wheat from The V.M. Remeslo Myronivka Institute of Wheat (MIP) were polymorphic by investigated genes that highlight the importance of $P p d-A 1 b, P p d-B 1 b$ and $P p d-D 1 a$ alleles for environmental conditions in the Ukraine. The haplotype (III) was detected in genotypes of 5 varieties - three of them from MIP and in varieties Etos and Yevdokiia. Also this haplotype was found in the well known old variety created in 1938 year - Odes'ka 3 by Guo et al. [14], thus transposable element (TE) insertion in the 1 intron of Ppd-D1 gene was historically present in the background of Ukrainian wheats. Simultaneously, spring wheat varieties have higher level of genetic polymorphism at Ppd-D1 loci than winter bread wheat varieties, maybe this locus and sensitivity to photoperiod is not critical for adaptability of spring wheat.
\end{abstract}

Keywords: photoperiod sensitivity, haplotypes, $P p d$-genes, wheat varieties

The growth and development of plants are significantly affected by light period. Cereals, including bread wheat (Triticum aestivum L.), react to change in the duration of light day by accelerating or slowing down the development. The degree of such reaction in bread wheat depends mainly from three genes that are localized in the second chromosome of each wheat subgenome A, B and D: Ppd-Al (2A), Ppd-B1(2B), Ppd-D1 (2D). The dominant alleles (a) of Ppd genes reduce sensitivity to duration of the day thus shorten the period until earing and genotypes with recessive alleles $(b)$ have a strong reaction to the photoperiod [17].

According to Langer et al. [16], Ppd-D1 gene is the major factor affecting flowering time in population of 410 winter wheat varieties (that was evaluated in multi-location field trials), explaining $58 \%$ of the genotypic variance. Copy number variation at the $P p d-B 1$ locus explains only $3.2 \%$ of the genotypic variance [16].

Чеботар Г., Бакума А., Філімонов В., Чеботар С., 2019 
Previously well characterized Ppd-Dla and sensitive $P p d-D 1 b$ alleles did not perfectly explain the broad adaptation of wheat to photoperiod variation. Guo et al. [14] detected several mutations in nucleotide sequences of $P p d-D 1$ which designated six haplotypes (I - VI) of the Ppd-D1 gene (Fig. 1). The highest expression level (pick time in the morning in shortday conditions) was observed for haplotype I with shortest days to heading [14]. All haplotypes also affected significantly other agronomic traits: days to heading, plant height and 1000-kernel weight tested in three environments in China [14].

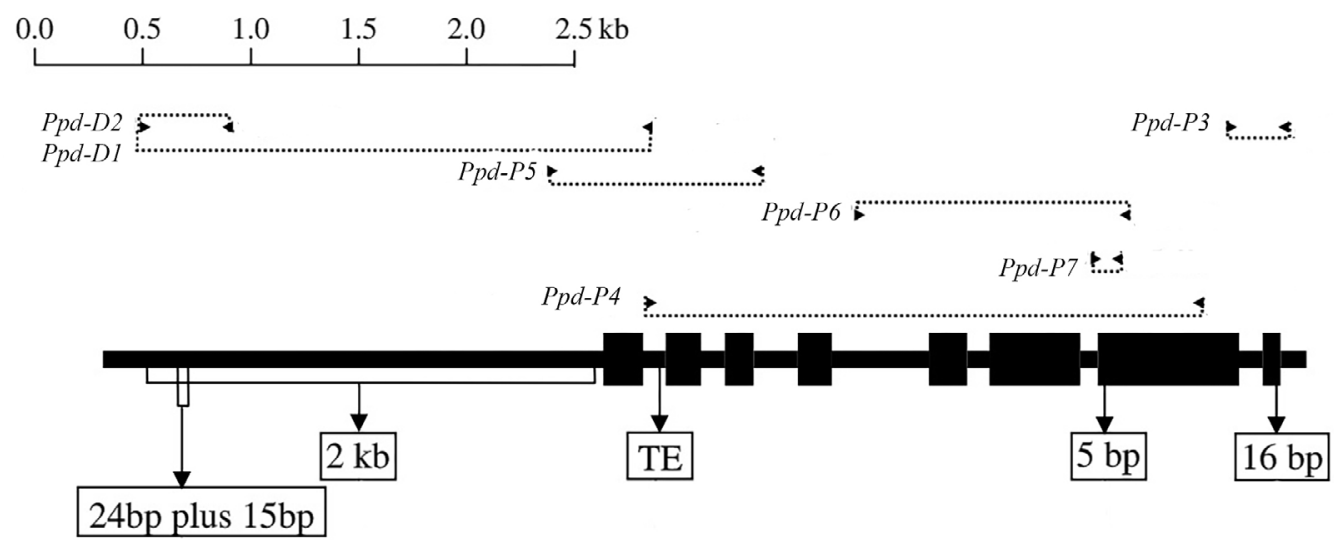

Fig. 1. Schematic structure of $P p d-D 1$ gene according to Guo et al. [14] with localization of the primers that have been applied in this investigation. Tall rectangles represent coding regions, low rectangles represent the introns, 5'UTR and 3'UTR regions

Previously there was no information about haplotypes of $P p d-D 1$ in Ukrainian varieties.

The aim of the work was to determine alleles of genes $P p d-A 1, P p d-B 1$ and haplotypes of $P p d-D 1$ for modern winter and spring wheat varieties using molecular markers.

\section{Materials and methods}

As the material there were used the mostly modern winter wheat varieties from: Bilat-

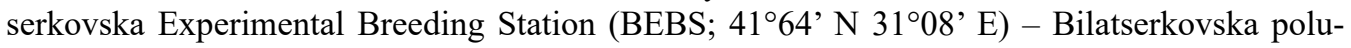
karlikova (1999), Olesya (2001), Pearlyna lisostepu (2001), Elegiya (2003), Yasochka (2006), Lybid (2006), Tsarivna (2008), Lisova pisnya (2008), Romantyka (2009), Vidrada (2010), Tschedra nyva (2011), Charodiyka bilotserkivska (2011), Vodogray bilotserkivsky (2014); The V.M. Remeslo Myronivka Institute of Wheat (MIP; 4964' N; 31 ${ }^{\circ} 08^{\prime}$ E) - Beregynya myronivs'ka (2016), Horlytsya myronivs'ka (2016), Economka (2008), Zymoyarka (2007), Kryzhynka (2002), Legenda myronivs'ka (2012), Myronivs'ka zolotovercha (at the varietal testing), Myronivs'ka 65 (2000), Myronivs'ka storichna (2009), Myronivs'ka rann'ostyhla (2002), Oberig myronivs'ky (2014), Pamyati Remesla (2009), Svitanok myronivs'ky (2014), Juviliyar myronivs'ky (2009); Poltava State Agrarian Academy (PSAA; 4971' N, 3451' E) - Dykan'ka (2005), Levada (2005), Sahaydak (2010), Sydor Kovpak (2008*), Tsarichanka (2013), Lyut'enka (2009*), Sonata poltavska (2018), Vilshana (2010), Govtva, Orzhytsa (2013), Karmelyuk (2015), Kolomak 3 (1997), Kolomak 5 (1997), Ukrainka poltavska (2000); spring wheat varieties - Krasa Polissia (2003) (Nosivska Breeding and Research Station), Ethos (Saaten-Union GmbH), Struna myronivs `ka (2008) (MIP), Yevdokiia (2007) (The Plant Production Institute nd. a. V. Ya. Yuryev of National Academy of Agrarian Sciences of Ukraine), Etiud (2006) (MIP), Nedra (2007) (National Scientific Center "Inctitute of Agriculture of NAAS"), Natasa (2009) (Institute of Field and Vegetable Crops, Novi Sad, and "NS SEME-UKRAINA", Torchyns'ka (Peasant farming "Roden' 10"). 
DNA was isolated according to [5]. Allele-specific PCR with the primers recommended by Beales et al. [10], Nishida et al. [19] and Gao et al. [14] to Ppd-A1, Ppd-B1, Ppd-D1 genes were used (Table 1).

The amplification products were fractionated by electrophoresis in $1 \%$ agarose gel and visualized using the Gel Doc TM XR + System Bio-Rad video system (USA) and also in $7 \%$ polyacrylamide gel strained with $\mathrm{AgNO}_{3}$, according to Promega [20]. The sizes of the amplified fragments were estimated using the standard molecular weight pUC19 / Msp I, Gene ruler 100 bp and ladder mix.

Table 1

PCR primers for detecting alleles of $P p d-A 1, P p d-B 1$ and $P p d-D 1$ in bread wheat, that have been applied in the investigation

\begin{tabular}{|c|c|c|c|c|}
\hline Locus & Allele & Forward and reverse primers & $\begin{array}{l}\text { Expected band } \\
\text { size }(b p)\end{array}$ & Reference \\
\hline Ppd-Al & $P p d-A 1 a$ & $\begin{array}{l}5 \text { '-cgtactccetccgtttcttt-3' } \\
5 \text { '-aatttacggggaccaaatacc-3, }\end{array}$ & 338 & Nishida et al. [19] \\
\hline$P p d-A 1$ & $P p d-A 1 b$ & $\begin{array}{l}\text { 5'-cgtactccctccgtttcttt-3' } \\
5^{\prime} \text {-gttggggtcgtttggtggtg-3' }\end{array}$ & 299 & Nishida et al. [19] \\
\hline Ppd-B1 & $\begin{array}{l}\text { Ppd-B1b } \\
\text { Ppd-B1a }\end{array}$ & $\begin{array}{l}\text { 5'-acactagggctggtcgaaga-3' } \\
5 \text { '-ccgagccagtgcaaattaac- } 3 \text { ' }\end{array}$ & $\begin{array}{l}1292 / \\
1600\end{array}$ & Nishida et al. [19] \\
\hline Ppd-D1 & Ppd-Dla & $\begin{array}{l}\text { 5'-acgectcccactacactg-3' } \\
\text { 5'-cactggtggtagctgagatt-3, }\end{array}$ & 288 or 2377 & Beales et al. [10] \\
\hline Ppd-D2 & $P p d-D 1 b$ & $\begin{array}{l}5 \text { '-acgectcccactacactg-3', } \\
5 \text { '-gttggttcaaacagagagc- } 3 \text {, }\end{array}$ & 414 or 453 & Beales et al. [10] \\
\hline Ppd-P3 & $\begin{array}{l}16 \text { bp insertion } \\
\text { Exon } 8\end{array}$ & $\begin{array}{l}\text { 5'-gatgaacatgaaacggg-3' } \\
5 \text { ' -gtctaaatagtaggtactagg-3, }\end{array}$ & 320 or 336 & Beales et al. [10] \\
\hline Ppd-P4 & TE deletion & $\begin{array}{l}5 \text { '-aggtccttactcatactcaatctca-3' } \\
5 \text { '-ctcccattgttggtgttgtta-3' }\end{array}$ & 2612 & Guo et al. [14] \\
\hline Ppd-P5 & $\begin{array}{l}2 \mathrm{~kb} \text { deletion or } \\
\text { TE insertion }\end{array}$ & $\begin{array}{l}5 \text { '-ccattcgaggagacgattcat-3', } \\
5 \text { '-ctgagaaagaacagagtcaa-3' }\end{array}$ & 1005 & Guo et al. [14] \\
\hline Ppd-P6 & $\begin{array}{l}5 \text { bp deletion } \\
\text { Exon } 7\end{array}$ & $\begin{array}{l}\text { 5'-gaatggcttctcctggtc }-3 \text { ' } \\
5 \text { '-gatgggcgaaaccttatt-3', }\end{array}$ & 1,032 or 1,027 & Guo et al. [14] \\
\hline$P p d-P 7$ & $\begin{array}{l}5 \text { bp deletion } \\
\text { Exon } 7\end{array}$ & $\begin{array}{l}\text { 5'-gtgtcctttgcgaatcctt }-3 \text {, } \\
\text { 5'-ttggagccttgcttcatct-3', }\end{array}$ & 184 or 179 & Guo et al. [14] \\
\hline
\end{tabular}

\section{Results}

According to our previos data [1] MIP wheat varieties have been differentiated into three groups, with different genotypes corresponding to the alleles of $P p d-1$ genes: I group - genotype Ppd-Ala Ppd-Blb Ppd-Dla - Horlytsya myronivs'ka (in later investigations we detected also $P p d-A 1 b$ allele in this variety); II group - genotype Ppd-Alb Ppd-BIb Ppd-Dla - Kryzhynka, Legenda myronivs'ka, Myronivs'ka 65, Myronivs'ka rann'ostyhla, Oberig myronivs'ky, Pamyati Remesla, Svitanok myronivs'ky, Juviliyar myronivs'ky, Economka; III group - genotype PpdAlb Ppd-B1b Ppd-D1b - Beregynya myronivs'ka, Zymoyarka, Myronivs'ka zolotovercha, Myronivs'ka storichna.

Almost all of these varieties had significant pair differences according to the earing date on the natural photoperiod, with a minimum difference of 5.38 days for Myronivs'ka storichna and Beregynya myronivs'ka, the maximum difference was observed between Myronivs'ka storichna and Zymoyarka - 27.82 days [1]. The difference in flowering time between Myronivs'ka storichna and Zymoyarka could not be precisely explained by the alleles of the $P p d-A 1 b P p d-B 1 b$ $P p d-D 1 b$. Also we detected significant differences $(\mathrm{P}=0,05 ; \mathrm{P}=0,01)$ between MIP varieties with Ppd-A1b Ppd-B1b Ppd-Dla genotype in natural photoperiod in vegetable vessels in each year (2014, 2015 and 2016). Thus, we analyzed haplotypes of Ppd-D1 gene in MIP wheat varieties. 
Winter wheat varieties from the breeding stations of Central (BEBS) and East (PSAA) region of Ukraine were characterized by alleles $P p d-A 1 b / P p d-B 1 b / P p d-D 1 a$. The start of the ear emergence for BEBS varieties differ not significantly in average 5 days in three years field trials.

Spring wheat varieties were divided into two groups: Ppd-A1b/Ppd-B1b/Ppd-D1a and $P p d-A 1 b / P p d-B 1 b / P p d-D 1 b$. Plants from varieties Krasa Polissia, Yevdokiia, Nedra and Torchyns'ka were characterized as strongly sensitive to photoperiod, whereas Etiud was weakly sensitive to photoperiod; Struna myronivs `ka, Natasa and Ethos have middle sensitivity to photoperiod according to State Register of Plant Varieties Suitable for Dissemination in Ukraine [3, 4].

As a result of investigation of $P p d-D 1$ sequence structure by using molecular markers recommended by Beales et al. [10] and Guo et al. [14] different haplotypes have been revealed among investigated varieties (Table 1). Two polymorphisms: a 2089-bp deletion upstream the coding region and the mariner-like transposable element (TE) insertion in intron 1 were found in Ukrainian bread wheat varieties (Table 2). Thus among 49 wheat varieties analyzed in this study, 40 varieties $(81.6 \%)$ had a 2089-bp deletion upstream of the coding region corresponded to the photoperiod-insensitive Ppd-Dla allele. One variety - Nedra - was heterogeneous according the presence of this deletion. The photoperiod-sensitive $P p d-D 1 b$ allele was detected in the 8 remaining varieties. In the genotypes of 5 varieties absence of the mariner-like TE in intron 1 of the Ppd-D1 gene were detected (Fig. 2, A, B). Thereby, 4 combinations of the 2 mentioned polymorphisms (Table 2) were detected in the tested wheat varieties.

Table 2

Ppd-D1 haplotypes identified in the investigated bread wheat varieties

\begin{tabular}{|c|c|c|c|c|c|c|}
\hline Ppd-D1 haplotype & Variety & $24 b p+15 b p$ & $2 \mathrm{~kb}$ & TE & $5 \mathrm{bp}$ & $16 \mathrm{bp}$ \\
\hline ת ת ת ת & Etiud & - & - & - & + & - \\
\hline $\mathrm{I} / \mathrm{II}$ & Nedra & - & $+/-$ & - & + & - \\
\hline II $^{*}$ & $\begin{array}{l}\text { Krasa Polissia, Torchyns'ka, } \\
\text { Zymoyarka } \\
\text { Myronivs'ka storichna, Myronivs'ka }\end{array}$ & - & + & - & + & - \\
\hline III $^{*}$ & $\begin{array}{l}\text { zolotovercha, Beregynya } \\
\text { myronivs'ka, Etos, Yevdokiia }\end{array}$ & - & + & + & + & - \\
\hline $\mathrm{VII}^{* *}$ & Other 39 varieties & - & - & + & + & - \\
\hline
\end{tabular}

Notes. ${ }^{*}-$ Haplotypes designated by Guo et al. [14]; ${ }^{* *}-$ Haplotype designated by Chen et al. [12]. Insertions and deletions are indicated by + and -, respectively

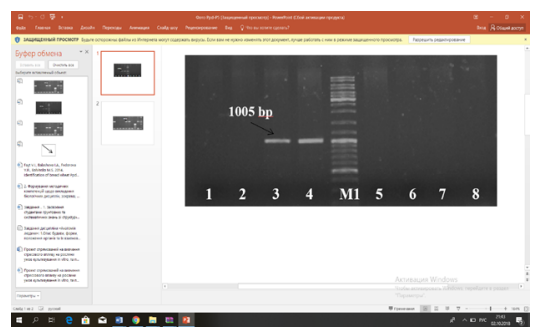

A

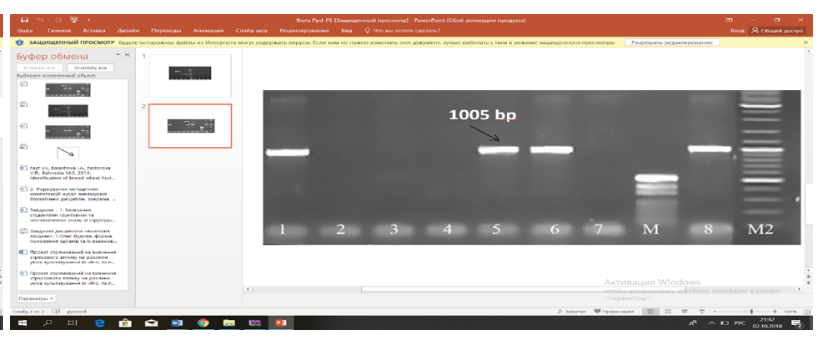

B

Fig. 2. Electrophoresis of PCR amplification fragments of wheat varieties with marker Ppd-P5: A - 1 Beregynya myronivs'ka; 2 - Myronivs'ka storichna; 3 - Zymoyarka (1); 4 - Zymoyarka (2); B - 1 Krasa Polissia; 2 - Ethos; 3 - Struna myronivs `ka; 4 - Yevdokiia; 5 - Etiud; 6 - Nedra; 7 - Natasa; 8 - Torchyns'ka; M - pUC 19 / Msp I; M1, M2 - molecular weight marker ladder mix

In variety Zymoyarka (MIP) TE insertion from the first intron was absent (Fig. 2A), all other varieties from MIP had this insertion. The presence of TE insertion in the first intron reduces the expression level of $P p d-D 1 b$ [12] and, as we assume, due to this, MIP varieties with $P p d-D 1 b$ 

Although in this variety the biggest difference between time of earing was detected on the natural and short photoperiod in artificial conditions as compared to with winter wheat varieties from MIP. According to Vlasenko et al. [2] variety Zymoyarka is not a descendent of varieties Ukrainka or Myronivs'ka 808 as a majority of other investigated MIP varieties, but could have in the pedigree cv. Krymka or germplasm of some other Ukrainian varieties. It is known that Krymka is one from the old and very heterogenic varieties. Deletion in exon 7 (size $5 \mathrm{bp}$ ) was absent in tested varieties from MIP.

Investigated varieties from BEBS and PSAA have not polymorphism in Ppd-D1 locus, all these varieties have 2089-bp deletion upstream of the coding region, TE insertion in 1 intron; 5 bp deletion in exon 7 and 16 bp insertion in exon 8 were absent in their genotypes and thus these varieties were corresponded to the VII haplotype.

\section{Discussion}

According to Langer et al. [16] allele Ppd-Dla is rare in the UK, Denmark, Germany, Poland, the Czech Republic and in Austria, and it is predominant in Eastern Europe and Russia. In our previous investigations among the 27 varieties of spring wheat from the collection of National Centre of Genetic Resources of Ukraine, $22.2 \%$ of tested varieties were characterized by the presence of the Ppd-Dla allele, indicating weak sensitivity of varieties to the photoperiod, $11 \%$ of varieties were heterogeneous, and $66 \%$ had the $P p d-D 1 b$ allele. All 34 investigated varieties from Institute of Cytology and Genetics of Siberian Branch of Russian Academy of Sciences were the carriers of allele Ppd-D1b [7]. We revealed the widespread distribution of the Ppd-D1b allele among the spring varieties of various climatic zones of Ukraine and the Russian Federation. It should be noted that among the modern winter wheat varieties from Ukraine, the varieties created in the south region mostly have the allele Ppd-D1a $[1,8,11]$. In this work we revealed that $79.6 \%$ of varieties corresponds to the VII haplotype and only one variety - to the I haplotype. In the investigations of Guo et al. [14], the varieties with I haplotype have the highest frequency among world wheat germplasm. The same situation was detected by Chen et al. [12] in the bread wheat from the Yellow and Huai Valley of China. The difference between I and VII haplotypes can be explained by absence of TE insertion in the first intron in the I haplotype. Absence of TE insertion can be identificated by presence of fragment $1005 \mathrm{bp}$ which is generated in PCR with marker Ppd-P5 and we have not tested amplification fragment 1005 bp with marker Ppd-P5 for 39 wheat varieties. The III haplotype was found in the famous old variety Odes'ka 3 by Guo et al. [14], thus TE insertion in the 1 intron of $P p d-D 1$ gene was historically present in the gene pool of Ukrainian wheats. In this investigation of Ukrainian wheat varieties the 5-bp deletion in exon 7, 16-bp insertion in exon 8 and a 24-bp plus a 15-bp insertions in the 2-kp upstream region were not found. Earlier Guo et al. [14] have found the genotypes that have 24-bp plus 15-bp insertions in the 2-kb upstream region among synthetic wheats and Aegilops tauschii Coss. accessions. In previous work Chebotar et al. [8] also detected 24-bp plus a 15-bp insertions and new variant of polymorphism - only 15-bp insertion (without 24-bp insertion) in the collection of Aegilops tauschii accessions.

Most Ukrainian varieties investigated in this work have Ppd-Dla $(81.2 \%)$ photoperiod insensitive allele, according to the previously known nomenclature, or characterized by the VII haplotype $(79.6 \%)$. Observed significant differences in different years between varieties with the same genotype that leveled off after combining of three years data, that could be due to the multidirectional effects of environmental factors in different years or the effects of other genetic systems that affect time of plants development, or modification variability, or epigenetic marks 
Г. Чеботар, А. Бакума, В. Філімонов, С. Чеботар

(such as levels of methylation).

Investigated in our work spring varieties Krasa Polissia, Yevdokiia, Etiud, Struna myronivs 'ka, Torchyns'ka were divided into the haplotypes of Ppd-Alb gene by Muterko et al. [18], they are: I - Krasa Polissia, Yevdokiia; III - Etiud and IV - Struna myronivs 'ka, Torchyns'ka and haplogroups AII - Krasa Polissia, Yevdokiia, Etiud and AI - Struna myronivs 'ka, Torchyns'ka.

According to Fayt et al. [6] among 129 winter wheat varieties from different regions of Ukraine and Russia that have been created mostly at the end of the 20-th century the frequency of allele $P p d-D 1 a$ was $77.5 \%$. Among varieties and landraces of wheat from Turkey [9], the frequency of $P p d-D l a$ is $60 \%$ in spring wheats, and in winter wheat varieties the frequency is $54 \%$. Among the 20 varieties created from 1960 to 2003 in Bulgaria, a large majority of which are winter, the frequency of this allele is $93.3 \%$ [15]. Yang et al. [21] in the study of 926 landrace and wheat varieties from China, showed the presence of Ppd-Dla in $66 \%$ of genotypes, while its frequency in landrace $-38.6 \%$, and in varieties $-90.6 \%$. The authors note that Ppd-Dla is present in all "improved varieties" developed and zoned after 1970, with the exception of spring wheat, created in high latitudes of Northwest China and winter varieties in Gansu and Xinjiang. According to Chen et al. [12] 89,6 \% of bread wheat from the Yellow and Huai Valley of China have Ppd-Dla. Most tested wheat varieties that are grown in Southern and Central Europe are insensitive to the photoperiod, while British varieties are the most susceptible [13]. Unfortunately, further large-scale genotyping of wheat germplasms from different geographic regions (except China) has not yet been performed in terms of photoperiod response alleles. In Ukraine there were few investigations of $P p d-D 1$ haplotypes earlier. The results of this study are useful as description of Ukrainian wheat germplasm and could be in demand for breeding of wheat varieties for better maturity and adaptability.

\section{Conclusions}

We have determined allelic characteristic of $P p d-A 1, P p d-B 1$ and $P p d-D 1$ loci for modern wheat varieties from Central and East regions of Ukraine. Most varieties have $P p d-A 1 b$ allele. With the primers recommended by Nishida et al. [19], the PCR fragment $1292 \mathrm{bp}$ that corresponds to $P p d-B 1 b$ allele were detected in all varieties. We have also detected haplotypes of Ppd-D1 gene. Among all investigated varieties the haplotype VII was the most common (it was present in $79.6 \%$ of varieties). Simultaneously, spring wheat varieties have higher level of genetic polymorphism at $P p d-D 1$ loci than winter bread wheat varieties. In 8 spring wheat varieties to the each of haplotypes II, III and VII were corresponded $25 \%$ of varieties ( 2 varieties), and by $12.5 \%$ ( 1 variety) accounted to haplotype I and heterogeneous variety Nedra. Among winter wheat varieties $90.3 \%$ (37 varieties) corresponds to the haplotype VII, $2.4 \%$ (1 variety) - II haplotype and 7.39 \% (3 varieties) - III haplotype. Maybe Ppd-D1 locus and sensitivity to photoperiod is not critical for adaptability of spring wheat.

Acknowledgments. The work was done within the framework of the Ministry of Education and Science KPKVK 2201040 the project № 569 «Polymorphism of wheat and soybean photoperiod sensitivity loci and plant development dependence on their allelic composition according to PCR analysis» (2017).

The authors are thankful for provided wheat material to Dr. N. V. Bulavka The V. M. Remeslo Myronivka Institute of wheat National Academy of Agrarian Sciences of Ukraine, Prof. L. A. Burdenyuk-Tarasevych Bila Tserkva research and Breeding Station of the Institute of Bioenergy Crops and Sugar Beet of the National Academy of Agricultural Science of Ukraine; Prof. V. M. Tytschenko Poltava State Agrarian Academy. 
Г. Чеботар, А. Бакума, В. Філімонов, С. Чеботар ISSN 0206-5657. Вісник Львівського університету. Серія біологічна. 2019. Випуск 80

\section{REFERENCES}

1. Бакума А. О., Булавка Н. В., Чеботар С. В. Генотипи сучасних миронівських сортів озимої м'якої пшениці за $P p d-A 1, P p d-B 1, P p d-D 1$-генами та їх чутливість до фотоперіоду // Вісн. ОНУ. Біологія. 2016. Т. 21. С. 75-88.

2. Власенко В. А., Кочмарський В. С., Колючий В. Т. та ін. Селекційна еволюція миронівських пшениць. Миронівка: Миронівський ін-т пшениці імені В.М. Ремесла, 2012. 326 с.

3. Державний реєстр сортів рослин, придатних для поширення в Україні. К., 2010.

4. Державний реєстр сортів рослин, придатних для поширення в Україні на 2018 рік. К., 2018. $468 \mathrm{c}$.

5. Использование ПЦР-анализа в генетико-селекционных исследованиях / под ред. Ю.М. Сиволапа. К.: Аграрна наука, 1998. С. 8-33.

6. Файт В. И., Баламова И. А., Федорова В. Р., Бальвинская М. С. Идентификация генотипов Ppd-1 сортов мягкой пшеницы методами генетического и STS-ПЦР анализа // Физиология растений и генетика. 2014. Т. 46. С. 325-336.

7. Чеботар $Г$. O. Алелі генів короткостебловості Rht8, Rht-B1, Rht-D1, нечутливості до фотоперіоду $P p d-D 1$ м'якої пшениці та їх ефекти на агрономічні ознаки: автореф. дис. ... канд. біол. наук: 03.00.15. О., 2012. $21 \mathrm{c}$.

8. Чеботар Г. О., Чеботар С. В., Бабенко Д. О. та ін. Алелі гена $P p d-D 1$ у зразках колекції Aegilops tauschii і м'якої пшениці // Biopolym. Cell. 2012. Vol. 28. P. 149-155.

9. Andeden E., Yediay F., Baloch $F$. et al. Distribution of vernalization and photoperiod genes (Vrn-A1, Vrn-B1,Vrn-D1, Vrn-B3, Ppd-D1) in turkish bread wheat cultivars and landraces // Cereal Res. Commun. 2011. Vol. 39. P. 352-364.

10. Beales J., Turner A., Griffiths S. et al. A Pseudo-Response Regulator is misexpressed in the photoperiod intensitive Ppd-Dla mutant of wheat (Triticum aestivum L.) // Theor. Appl. Genet. 2007. Vol. 115. P. 721-723.

11. Chebotar G. O., Motsnyy I. I., Chebotar S. V., Sivolap Yu. M. Clarification of the Rht8Ppd-D1 gene linkage on the 2D chromosome of winter bread wheat // Cytol. Genet. 2013. Vol. 47. P. 70-74.

12. Chen F., Gao M., Zhang J. et al. Molecular characterization of vernalization response genes in bread wheat from the Yellow and Huai Valley of China // BMC Plant Biol. 2013. Vol. 13. P. 199.

13. Foulkes M. J., Sylvester-Bradley R., Worland A. J., Snape J. W. Effects of a photoperiod-response gene $P p d-D 1$ on yield potential and drought resistance in UK winter wheat // Euphytica. 2004. Vol. 135. P. 63-73.

14. Guo Z., Song Y., Zhou R. et al. Discovery, evaluation and distribution of haplotypes of the wheat Ppd-D1 gene // NewPhytol. 2010. Vol. 185. P. 841-851.

15. Kolev S., Ganeva G., Christov N. et al. Allele variation in loci for adaptive response and plant height and its effect on grain yield in wheat // Agricultural and Environmental Biotechnology. 2010. Vol. 24. P. 1807-1813.

16. Langer S. M., Longin C. F. H., Würschum T. Flowering time control in European winter wheat // Front Plant Sci. 2014. Vol. 5. P. 537. doi: 10.3389/fpls.2014.00537

17. McIntosh R. A., Dubcovsky J., Rogers W. J. et al. Catalogue of Gene Symbols for Wheat. 12th International Wheat Genetics Symposium 8-13 September 2013 Yokohama, Japan. https:// maswheat.ucdavis.edu/CGSW/

18. Muterko A., Kalendar R., Cockram J., Balashova I. Discovery, evaluation and distribution of haplotypes and new alleles of the Photoperiod-A1 gene in wheat // Plant Mol. Biol. 2015. Vol. 88. P. 149-164. 
Г. Чеботар, А. Бакума, В. Філімонов, С. Чеботар ISSN 0206-5657. Вісник Львівського університету. Серія біологічна. 2019. Випуск 80

19. Nishida H., Yoshida T., Kawakami K. et al. Structural variation in the 5 ' upstream region of photoperiod-insensitive alleles $P p d-A 1 a$ and Ppd-Bla identified in hexaploid wheat (Triticum aestivum L.), and their effect on heading time // Molecular Breeding. 2013. Vol. 31. P. 27-37.

20. Promega Technical Manual. Gene Print. STR Systems. Printed in USA. Revised. 1999. Vol. 7. 52 p.

21. Yang F. P., Zhang X. K., Xia X. C. et al. Distribution of the photoperiod insensitive Ppd-D1a allele in Chinese wheat cultivars // Euphytica. 2009. Vol. 165. P. 445-452.

Стаття: надійила до редакиії 30.11.18

доопрацьована 25.02.19

прийнята до друку 28.02.19

\title{
ГАПЛОТИПИ РРD-D1 ГЕНА Й АЛЕЛІ РPD-A1 І РPD-В1 В УКРАЇНСЬКИХ СОРТАХ М'ЯКОЇ ПШЕНИЦІ
}

\author{
Г. Чеботар, А. Бакума, В. Філімонов, С. Чеботар
}

${ }^{1}$ Одеський національний університет імені I.I. Мечнікова вул. Дворянська, 2, Одеса 65082, Украӥна

${ }^{2}$ Селекційно-генетичний інститут - Національний ичентр насіннєзнавства та сортовивчення

Овідіопольська дорога, 3, Одеса 65036, Україна

e-mail: s.v.chebotar@onu.edu.ua

\begin{abstract}
Сучасні українські сорти м'якої пшениці недостатньо охарактеризовані за алелями генів $P p d$, також недостатньо інформації щодо гаплотипів за цими генами у вітчизняному генетичному пулі пшениці. Домінантні алелі (a) генів $P p d-A 1$ (2A), $P p d-B 1$ (2B), $P p d-D 1$ (2D) знижують чутливість рослин пшениці до фотоперіоду, тим самим скорочуючи період до колосіння, а рецесивні алелі $(b)$ характерні для генотипів зі сильною реакцією на фотоперіод. Гаплотипи гена $P p d-D 1$ також можуть впливати на фотоперіодичну чутливість. За результатами ПЛР-аналізу з алель-специфічними праймерами більшість досліджених сортів характеризувалися алелями $P p d-A 1 b$ та $P p d-B 1 b .40$ сортів (81,2 \%) мали делецію перед кодуючим регіоном $P p d-D 1$ гена, яка відрізняє Ppd-Dla алель. Також ми проаналізували гаплотипи гена $P p d-D 1$. Було показано наявність VII гаплотипу гена $P p d-D 1$ у 79,6 \% сортів. Сорти 3 гаплотипами I (2 \%), II (6 \%), III (10\%) гена Ppd-D1 траплялися з меншою частотою. Один сорт був гетерогенним за алелями $P p d-D l a / b$. Із досліджених лише сорти озимої м'якої пшениці Миронівського інституту пшениці імені В.М. Ремесло (МІП) були поліморфними за генами $P p d-1$, що підкреслює важливість алелів $P p d-A 1 b, P p d-B 1 b$ та $P p d-D 1 a$ для вирощування рослин в еколого-географічних умовах України. Гаплотип (III) був виявлений у генотипах 5 сортів - у трьох з МІП і в ярих сортах Етос та Євдокія, також цей гаплотип детектовано у стародавньому та відомому сорті Одеська 3 (створеному у 1938 р.) в роботі Guo et al. [14], таким чином, TE в 1 інтроні гена $P p d-D 1$ був історично наявним у сортах пшениці в Україні. Цікаво, що сорти ярої пшениці мають більш високий рівень генетичного поліморфізму в локусі $P p d-D 1$, ніж сорти озимої м'якої пшениці. Можливо, цей локус і чутливість до фотоперіоду не $\epsilon$ критичними для адаптивності ярої пшениці.
\end{abstract}

Ключові слова: чутливість до фотоперіоду, гаплотипи, $P p d$-гени, сорти пшениці 